\title{
Mirella Korzeniewska-Wiszniewska*
}

\section{Dynamics of the Serbian EU accession process - Key issues and the challenges of state democratisation in an era of populism}

\begin{abstract}
The current Serbian authorities (aligned with the Serbian Progressive Party) have pushed Serbia towards effective reforms over the past several years and improved its image on the international arena through an intensified diplomatic offensive after 2015. This has led to a situation in which the Serbian state became a political and economic partner in both regional and integration projects. The latter is demonstrated by the arduous but progressive accession process to the European Union.

After 2000, international and Serbian public opinion greeting the end of the regime of Slobodan Milošević expected rapid democratisation of the state based on statements by Serbian politicians who had declared a West European course of the state. The short-lived rule of Prime Minister Zoran Đinđić, confirmed this; however, the policy of his successors was no longer so unambiguous. For almost a decade, Serbia oscillated between populism and declared democratisation, without making major changes, expected by both society and the European Union.

When after the year 2012 the Serbian Progressive Party came to power (the party was founded as a conservative grouping and had radical roots), it seemed that the Serbian state would be pushed towards a more conservative, anti-European and nationalist direction. However, that did not happen. Opinion about the last six years of the group's rule is varied. This paper aims to try to answer the question whether during the party's rule, Serbia has been democratising and whether in this era of nationalist movements and populism, the country has a chance at real democratisation and finishing the process of accession to the EU?
\end{abstract}

Keywords: Serbia, democratisation

* Mirella Korzeniewska-Wiszniewska - PhD (hab.), is an assistant professor at the Institute of Political Science and International Relations, Jagiellonian University in Kraków, Poland. ORCID: https:// orcid.org/0000-0001-7631-0601. E-mail: m.korzeniewska-wiszniewska@uj.edu.pl. 


\section{Introduction}

- Over several years, the current Serbian government (Serbian Progressive Party, Srpska napredna stranka, SNS) has pushed Serbia toward effective reform, improved its image on the international arena, and elevated the country to the status of a political and economic partner in both regional and integration politics, as evidenced by the hard but slowly advancing EU accession process. From a foreign perspective, in the 2010s, Serbia has decided to bet on young politicians, disavowing any links to the authorities of the 1990s, and steering the nation on a pro-Western and democratic course that in the first decade of the century had been limited only to verbal declarations. Apart from the term of the former Serbian Prime Minister (2001-2003) Zoran Đinđić, cut short by his assassination, the first decade was a festival of hollow promises and declarations made by governments unable to usher in any real reforms that would also be seen and felt by the common citizen, who had hoped for an efficient state based on the European model (meaning the EU as a desirable standard) ever since the collapse of the former Yugoslavia (FRY). For nearly a decade, Serbia oscillated between declarative democratisation and de facto populism, failing to introduce the reforms expected either by its society or the EU. In 2012, with the accession to power of the SNS, which ran on an essentially conservative and radical ticket, it seemed that the state would be propelled on an even more conservative, nationalist and anti-European path. However, this is not what happened. In contrast to the conservative President Tomislav Nikolić, the new, young Prime Minister Aleksandar Vučić appeared ready to push forward important reforms and democratise the country, even though his image makeover was quite radical. In the 1990s, he had earned a reputation as a 'national firebrand': in his capacity as the Minister of Information in the government of Slobodan Milošević, he helped introduce penalties for dissident journalists and initiated a block on foreign TV channels, which marked him out as a persona non grata in the EU (in 2014, he even issued an apology for these actions) $)^{1}$. Following the 2012 elections, however, he rebranded himself as an 'occidentalist' while main-

1 Srpska napredna stranka, I'm obsessed with Kosovo, 15.05.2018, https://www.sns.org.rs/en/novosti/vesti/vucic-im-obsessed-kosovo [11.10.2019]. 
taining very good relations with Russia, he began to tighten the alliance with the EU and successfully opened up the Serbian market to foreign investment. Thanks to these moves, the power of Vučić, now as the president of Serbia (since 2017), has relied, as his critics emphasize, on the support granted by Western powers in recognition of his role in the service of global capital and Western interests. Such policies, and the trust vested in Vučić by the West, achieved by the Serbian diplomatic offensive since 2015, have allowed the president and his team to quickly consolidate their power and win a majority in earlier parliamentary elections. As a result, the ruling party and its leader no longer need coalition support to introduce the reforms that suit them. This power consolidation has led some to liken Vučić to Hungarian Prime Minister Viktor Orbán, based on similarities in their political system reforms and the way in which they are introduced. According to the latest Freedom House report, Serbia is now labelled as 'partly free'; no more than a year ago, with seven more points, it was still classified as 'free.' The greatest score loss was reported in political rights, civil liberties, and media freedom ${ }^{2}$.

Long perceived as a country with a third-world mentality, plagued by the post-conflict syndrome, Serbia has quickly revamped its image to seriously consider taking on the role of regional hegemon, to which it has always aspired. The goal of the incumbent government is to finalise the accession process and join the EU, which, at least in the region, is treated as a clean bill of health, a sign of a well-developed economy, international trust and an equal political footing with other EU member states. This can be a big challenge for the Serbian authorities because of the political, social, and economic situation, which is not conducive to further enlargement of the EU. We could note the economic slowdown and the Union's internal problems related to Brexit and the consequences of Catalan separatism. Critical assessment of the effects of the accession of Bulgaria and Romania, perceived as countries admitted too early to the EU, also plays a huge

2 Freedom House, Freedom in the World 2019, https://freedomhouse.org/report/freedomworld/2019/serbia [13.10.2019]; Freedom House, Freedom in the World 2018, https://freedomhouse.org/report/freedom-world/ freedom-world-2018 [13.10.2019]; O. Karabeg, Da li će Vučić vladati Srbojom dokle bude hteo, Radio Slobodna Evropa, 06.08.2017, https://www.slobodnaevropa.org/a/da-li-ce-vudic-vladati-srbijom-dokle-bude-hteo/28660615.html [13.10.2019]. 
role here. In addition, the refugee crisis in which Serbia played an important role, which was appreciated by the EU, led to the situation in which the European Union still focus on its own internal problems. On the other hand, EU politicians have clearly expressed anxiety about the continued of political and military strong ties (also important economic in nature) with Russia.

The purpose of this paper to analyse the actions of the current Serbian government which, on the one hand, aims to finalise the EU accession process, and on the other, curtails democracy inside the country, as well as to investigate the spaces of possibility for the democratisation of state structures and internal policy in the era of consumerist populism characteristic of the 2010s. The analysis will present the policies of the Serbian authorities and their EU accession milestones, as discussed in detail in the reports by the European Commission or Delegation. The activities of social movements and non-governmental organisations, on the other hand, will be shown based on texts penned by independent journalists and academics, as well as articles from selected media.

\section{The path toward democratisation and Europeanisation of the state after 2000}

No important measures to build relations with the EU in the postcommunist period were taken until the beginning of the $21^{\text {st }}$ century, owing to the international isolation of the FRY in the 1990s and the armed conflicts that erupted in the wake of the break-up of the state, in which the West firmly took the side of the Serbian antagonists. Even though the most recent conflict broke out in 1999 (the Kosovo War), a pro-Western political course was adopted after the regime change of 2000; this met with an ambivalent response from Serbian society, which, on account of the international relations in preceding years but also its history at large, was more naturally inclined to look for political allies in the East (particularly in the Russian Federation). As indicated by contemporary opinion polls, however, although they accused the West of cynical and self-serving policies, Serbs expressed a marked preference for the Western lifestyle over that of the average Russian. Steering the country on a pro-Western course looked like the only 
prospect for effective democratisation and modernisation, achievable through close cooperation with highly developed EU member states ${ }^{3}$.

The new Serbian government (still within the framework of the FRY) did not immediately win the trust of the Western powers, or Russia, despite its unequivocally pro-Western prime minister, Đinđić, and the quick EU accession plan promoted by Belgrade. Despite this international scepticism, however, a few days after the political change in Serbia (5 October 200o), the new president of the FRY, Vojislav Koštunica, was invited to attend the EU summit on October 8, 200o, in Biarritz, presided over by France, and Serbia was included in the Stabilisation and Association Process for Western Balkans, launched in June $1999^{4}$. In 2000, the EU lifted tariffs on goods from the FRY, but the slow pace of reforms and unresolved war issues meant that Serbia would only sign the Stabilisation and Association Agreement (SAA) with the EU at the end of April 2008, effective as of the second half of 2013.

Established in 2002 by the Government of the Republic of Serbia, the European Integration Office regularly monitored public attitudes toward EU accession. On the one hand, the EU was perceived as a promise of a better life for the common citizen; on the other, however, its image was tainted by European involvement in the resolution of the crisis in Yugoslavia in the 1990s. The resulting lack of consensus meant that work in Serbia's parliament, the Skupština, would often run into periods of standstill and talks with Brussels constantly teetered on the verge of collapse. More often than not, the integration process failed to win a parliamentary majority, as evidenced by the resolution on association with the EU, passed only in October 2004, which defined EU accession as a fundamental strategic and state interest, and was backed by just 129 of the 250 deputies ${ }^{5}$.

3 Conditions imposed by the EU, which contributed to the slowdown of the accession process, meant that a few years later, as an alternative, the concept of cooperation with the BRICS countries appeared, naturally alongside the Russian Federation. For more, see M. Korzeniewska-Wiszniewska, Charakter współczesnych relacji serbsko-rosyjskich, [in:] I. Stawowy-Kawka (ed.), Międzycywilizacyjny dialog w świecie słowiańskim w XX i XXI wieku. Historia - religia - kultura polityka, Kraków 2012.

4 Ministarstvo za evropske integracije Republike Srbije, Istorijat odnosa SrbijeiEU, http://www.mei. gov.rs/srl/srbija-i-eu/istorijat-odnosa-srbije-i-eu/ [09.10.2019].

5 Z.Vučković, Transformacje systemu społeczno-politycznego w Serbii po 2000 r., Kraków 2014 [Doctorate not published. Access courtesy of the author]. 
In the nearly two decades since 2000, the lowest level of support for EU accession (a little over 50 percent in favour and 30 percent against) was reported between 2010 and the end of 2014. In 2015, the figure began to grow and rose to nearly 59 percent in a Gallup poll (55 percent declared they would vote in favour); at the same time, however, 66 percent of respondents refused to recognise the independence of Kosovo, even as a prerequisite for accession, although 58 percent did support further talks between Belgrade and Priština. According to public opinion, other conditions that would have to be met before Serbia could join the EU also included fighting corruption and organised crime and promoting economic stabilisation. Of Serbs, 57 percent expected to see Serbia in the EU within the next 10 years ${ }^{6}$.

It must be noted that the organisation of the state, which, from February 2003 onward, functioned as Serbia and Montenegro, also complicated potential negotiations, because of the problem of separate markets. A referendum to decide the independence of Montenegro was scheduled for 2006; in light of its uncertain outcome, the talks came up against an additional stumbling block. Nevertheless, in 2005 , both republics were deemed ready to finalise negotiations on the SAA, which Serbia later signed as a sovereign and independent state ${ }^{7}$. Considerable advances in the integration of Serbia with Western Europe (such as the Central European Free Trade Agreement, CEFTA, or visa-free travel), however, came to a temporary halt in 2006 and 2007 when Serbia was criticised for its inadequate cooperation with the International Criminal Tribunal for the former Yugoslavia (ICTY) at The Hague. A formal application for EU membership was only filed at the end of 2009, with official candidate status being granted in early March 2012. The decision to start accession talks followed on June 28, 2013, and in January 2014 the negotiations finally kicked off. Out of the 35 negotiation chapters on the agenda, as of October 2019, 17 had

6 Ibidem.

7 Ministarstvo za evropske integracije Republike Srbije, Istorijat odnosa Srbije...; Ministarstvo za evropske integracije Republike Srbije, Споразум о стабилизацији и придруживаюу између Европских заједница и њихових држава чланица, са једне стране, и Републике Србије, са друге стране [Sporazum o stabilizaciji i pridruživanju između Evropskih zajednica injihovih država članica, sa jedne strane, i Republike Srbije, sa druge strane], http://www.mei.gov.rs/upload/documents/sporazumi_sa_eu/ssp_prevod_sa_anexima.pdf [09.10.2019]. 
been opened and two temporarily closed (10 intergovernmental conferences have been held to date $)^{8}$.

\section{Key challenges and obstacles to the Serbian state 3 .in the first decade of the $21^{\text {st }}$ century}

Regarding the efforts of Serbia to change after the Milošević period and expecting quick accession to the EU by Serbian society, we can notice a few specific elements that the country has had to face. Moreover, these were elements of special concern to the EU: cooperation with the ICTY (and handing over to the tribunal persons suspected of committing crimes during the wars), finding a solution to the situation of the southern Serbian province of Kosovo after the war in 1999, and developing regional cooperation.

Cooperation with The Hague tribunal was one of several preconditions for starting accession talks with the Serbian state. Another prerequisite, equally controversial for the Serbian public, had to do with the regulation of relations with the state of Kosovo. The documents initially formulated it as a call for stabilisation through bilateral dialogue under the auspices of Brussels. The condition, however, soon came to be interpreted more broadly as a call for Belgrade to recognise the independence of Kosovo; though never explicitly expressed in any document, it began to come up in the statements of politicians who visited Serbia in the 2010s, and especially those of German delegates, who made it clear that this was the ultimate objective of the support for the dialogue between Belgrade and Priština. Such pronouncements were and continue to be made openly, leaving no doubt as to the nature of the demand. The need to regulate relations with Priština was first brought up in 2011, during a visit of a Bundestag delegation to Belgrade when the German deputies clearly stated that Serbia could not join the EU before it recognised the independence of Kosovo. Their words were echoed by European Commissioner Stefan Füle, who commented that even though this was not a precondition for further Serbian integration with the Union, no EU state was prepared to accept a new member with any unresolved issues in relation 
to its neighbours. Contacts between Serbia and Kosovo were thus initiated at the beginning of 2011. In late February and early March 2011, the two countries embarked on a series of talks designed to regulate issues of most pressing urgency for the residents of Kosovo, which required the participation of Belgrade, such as birth and land registers, cadastral records, air traffic, telecommunications, tariff stamps, and CEFTA membership. In July 2011, the National Agency for Regional Development in Serbia and the Agency for the Support of Small and Medium-Sized Enterprises in Kosovo signed an agreement to establish a joint institution that would be active on the territories of both countries. On and off, the talks have continued to this day. The most important issue currently on the agenda concerns plans for enabling the activities of the Community of Serb Municipalities, based on an agreement between Belgrade and Priština, which are rejected by the Albanian side due to the argument that it would create de facto Serbian autonomy and could lead to the secession of Serbian-inhabited parts of the country ${ }^{9}$.

Apart from the issue of Kosovo, other external relations that play a vital role in the accession process from the perspective of Brussels include regional cooperation. Fostering good neighbourly relations is a challenge pursued on two levels, economic and political; in what follows, I will focus on the latter. Since the break-up of Yugoslavia, the economic sphere in the region has experienced unimpeded growth. Even though partnerships were primarily struck up with highly developed countries, which offered more competitive goods and supported the development of individual countries, former Yugoslavian republics also forged links of intense mutual cooperation in different economic areas. This was because of not only the prior links between the different regions within socialist Yugoslavia but also the situation after its collapse when businesses were broken up by the rise of new

9 Z.Vučković, op. cit., passim; Kosovo Progress Essential, Fule Tells Serbia, Balkan Insight, 16.02.2012, https://balkaninsight.com/2012/02/16/progress-in-kosovo-dispute-remains-condition/ [07.10.2019]; Fule: Ne tražimo od Srbije da prizna Kosovo, Klix, 23.10.2014, https://www.klix.ba/ vijesti/regija/fule-ne-trazimo-od-srbije-da-prizna-kosovo/141023173 [07.10.2019]. See more on the topic: S. Gashi, I. Novaković, Od tehničkih sporazuma do sveobuhvatne normalizacije. Odnosi između Beograda iPrištine, Beograd 2017, http://library.fes.de/pdf-files/bueros/belgrad/13821.pdf [08.10.2019]; Kosovski Demokratski Institut, Dijalog Kosovo-Srbija: izazovi idalji koraci, March 2018, http://kdi-kosova.org/wp-content/uploads/2018/04/18-Sfidat-SRB-04.pdf [08.10.2019]. 
states and international cooperation was the only way to guarantee their continued activity. While the economic sphere was ruled by a spirit of pragmatism, diplomatic relations encountered more stumbling blocks, especially in Serbia, which emerged from the conflicts of the 1990s with heavy baggage that largely determined its internal affairs and foreign policy. The countries of the region, however, have shown goodwill in mutual diplomatic relations, motivated either by economic interest or, in the case of Serbia, the presence of a Serbian minority, with an important role played by external pressure related to the accession process. Apart from the case of Kosovo, already discussed above, it is also important to draw attention to the thorny relations between Serbia, Croatia, and Bosnia and Herzegovina. Although the difficult process of relation-building has been underway for 20 years, its fragility still often comes to light, usually on occasions related to the war.

On account of its central location in the Balkan Peninsula, Serbia has always aspired to the role of regional hegemon, an important state to be reckoned with in regional politics. Because of the political regime that isolated it on the international arena until 2000, it was not until the dawn of the $21^{\text {st }}$ century that it could finally begin to build its position in the region. Currently, Serbia is a partner of most (if not all) regional initiatives designed to impact multi-level political and economic stability in the area. In 2000, it joined the South-East European Cooperation Process (SEECP), aimed at strengthening regional cooperation, and the Central European Initiative (CEI), established to fund regional projects from the resources of its member states, which included 10 EU countries, the countries of Western Balkans, and the socalled European Neighbourhood (Belarus, Ukraine, and Moldova). In the same year that its political isolation ended, Serbia also joined the Adriatic and Ionian Initiative, composed of eight countries ${ }^{10}$ working together in the fields of tourism, culture, academic exchange, transport and maritime cooperation, environmental protection, including fire safety, as well as partnerships between small and medium-sized 
enterprises ${ }^{11}$. An important role in regional cooperation is also played by the question of the Danube and the Sava rivers. To regulate the issue, in 2003, Serbia signed an agreement ('Okvirni sporazum za sliv reke Save', or OSSRS) ${ }^{12}$, which addressed the order of navigation, sustainable water-management strategies, and the protection of the ecosystem and its waters from harmful impact. Serbia has also worked with other EU member countries within the framework of the 'EU Strategy for the Danube Region' (2011). The strategy is based on three basic pillars: 1 . connectivity and communications; 2 . environmental protection, risk prevention and sustainable use of natural resources; 3. social, economic, and institutional development ${ }^{13}$.

In 2015, the Balkan Peninsula became the flashpoint of the refugee crisis, sparking the need for cooperation in yet another area. On a regional scale, the countries of the Western Balkans had signed a special agreement in 2004, based on the stabilisation pact of 2002. The Regional Initiative for Migration, Asylum and Refugees, which meets at least twice a year, addresses not only the challenges of asylum and migration flows but also border management, visa regimes, and the repatriation of displaced persons ${ }^{14}$.

In the economic sphere, after the proclamation of independence in 2006, Serbia became a party to CEFTA, a multilateral free trade agreement in Central and Eastern Europe ${ }^{15}$.

It should be noted that despite the complexities of the not so distant past, the countries of the Western Balkans and the peninsula at large generally support one another in their aspiration to join the EU. Formal support, for instance, is the objective of the Brdo-Brioni process, initiated in 2010, which aims to foster a spirit of cooperation and strengthen the regional bonds between countries, as well as the Berlin Process, established by German Chancellor Angela Merkel in 2014, which represents the interests of the Western Balkan region as a whole. Another, more time-hallowed, initiative that encompasses the

11 Ministarstvo spoljnih poslova Republike Srbije, Regionalne inicijative, http://www.mfa.gov.rs/sr/ index.php/spoljna-politika/eu/regionalna-saradnja?lang=lat [20.09.2019].

12 Ibidem. Other parties to this agreement are Bosnia and Herzegovina, the Republic of Croatia, and the Republic of Slovenia. 
whole region is the Visegrad Group, which actively supports NGOs and individuals by granting subsidies, individual scholarships and organising art workshops to promote the exchange of ideas within the region and between involved countries. Regional cooperation is also promoted by the youngest institution, active since 2016, the Regional Youth Cooperation Office ${ }^{16}$.

\section{EU accession process - oand relations with the EU after 2012}

As for the internal transformation of the Serbian state and its focus on integration with the EU, it should be pointed out that dynamic reforms and a clear acceleration in this respect, as mentioned before, could only be observed in the second decade of the $21^{\text {st }}$ century, after the rise to power of the SNS. One could say that the first decade was a time of lost opportunities, untapped by the declaratively pro-European ruling parties, symbolised by the former President Boris Tadić. As early as in June 2002, the European Council recognised Serbia (FRY) as a potential candidate for EU membership, a declaration confirmed three years later in Thessaloniki (considering that, in 200o, Serbia optimistically estimated it would be able to join the EU in 2004, this just went to show how slow the reforms had really advanced). However, it was not until 2004 that Serbia signed the SAA, which then took nine more years to come into force (2013). At long last, the country achieved official EU candidate status in 2012. In 2013, the European Parliament passed a resolution on Serbian development and decided to start official talks by January 2014. The plan materialised: the first intergovernmental conference took place in Brussels on 21 January 2014, marking the formal launch of talks; later the same year, the Serbian government submitted a 'National Programme for the Adoption of the Acquis Communautaire' for the 2014-2018 period. Then, at the end of the year, Brussels hosted a session of the Council for Stabilisation and Association ${ }^{17}$. 
In March 2015, a meeting was held to finalise the process of a legal compliance review, and in August, Serbian authorities appointed the members of the negotiating team. At the end of the year, the first two negotiation chapters were opened, concerning financial control (Chapter 32$)^{18}$ and so-called 'other issues' (Chapter 35$)^{19}$, which will include matters related to the dialogue between Serbia and Kosovo ${ }^{20}$. Half a year later, in the middle of 2016, two further chapters were opened: judiciary and fundamental rights (Chapter 23$)^{21}$, and justice, freedom and security (Chapter 24$)^{22}$; followed, later the same year, by two more - public procurement (Chapter 5$)^{23}$ and science and research (Chapter 25) ${ }^{24}$. In 2017, a record was set for the number of new

pregled odnosa Republike Srbije iEvropske Unije od 2005. godine do otvaranja pristupnih pregovora], http://kurs-pregovori.mei.gov.rs/?page=uvod [14.10.2019].

18 Vlada Republike Srbije, Преговарачка позиција Републике Србијеза Међувладинуконференцију o приступану Pепублике Србије Европској унији за поглавље 32 Финансијски надзор [Pregovaračka pozicija Republike Srbije za Međuvladinu konferenciju o pristupanju Republike Srbije Evropskoj uniji za poglavlje 32 Finansijski nadzor], Beograd 2014, http:// www.mei.gov.rs/upload/documents/pristupni_pregovori/pregovaracke_pozicije/pg32_pregovaracka_pozicija_srb. $\operatorname{pdf}[13.10 .2019]$.

19 Konferencija o pristupanju Evropsku Uniju, Приступни документ. Заједничка позиција Европске Уније. Поглавље 35 остала пuтањ а [Pristupni dokument. Zajednička pozicija Evropske Unije. Poglavlje 35 ostala pitanja], Brisel 2015, http://www.mei.gov.rs/upload/documents/pristupni_ pregovori/pregovaracke_pozicije/pg35_zajednicka_pozicija_eu.pdf [13.10.2019].

20 Ministarstvo za evropske integracije Republike Srbije, Хронолошки преглед... [Hronološki pregled....].

21 Vlada Republike Srbije, Преговарачка позиција Републике Србије у оквиру Међувладине конференције о приступању Републике Србије Европској унији за Поглавље 23. „Правосуђе иосновна права" [Pregovaračka pozicija Republike Srbije u okviru Međuvladine konferencije o pristupanju Republike Srbije Evropskoj uniji za Poglavlje 23. „Pravosuđe i osnovna prava"], Beograd 2016, http://www.mei.gov.rs/upload/documents/pristupni_pregovori/pregovaracke_pozicije/pg_23_ pregovaracka_pozicija_srbije.pdf [13.10.2019].

22 Vlada Republike Srbije, Преговарачка позиције Републике Србијеза Међувладинуконференцију o приступању Републике Србије Европској унији за Поглавље 25 "Наука и истраживање" [Pregovaračka pozicije Republike Srbije za Međuvladinu konferenciju o pristupanju Republike Srbije Evropskoj unijiza Poglavlje25 „Nauka istraživanje"], Beograd 2016, http://www.mei.gov.rs/upload/ documents/pristupni_pregovori/pregovaracke_pozicije/pg_poglavlje_pg_25.pdf [13.10.2019].

23 Vlada Republike Srbije, Преговарачка позиција Републике Србије за међународну конфееренцију о приступану Републике Србије Европској Унији а проговорачко поглавље 5-јавне набавке [Pregovaračka pozicija Republike Srbije za međunarodnu konferenciju o pristupanju Republike Srbije Evropskoj Uniji za progovoračko poglavlje 5 - javne nabavke], Beograd 2016, http://www.mei. gov.rs/upload/documents/pristupni_pregovori/pregovaracke_pozicije/pg_pozicija_pg_5.pdf [13.10.2019].

24 Vlada Republike Srbije, Преговарачка позиције Републике Србијеза Међувладину конференцију о приступаюу Pепублике Србије Европској унији за Поглавље 25... [Pregovaračka pozicije Republike Srbijeza Međuvladinu konferenciju o pristupanju RepublikeSrbije Evropskojuniji za Poglavlje $25 \ldots]$. 
chapters, when a total of six were opened: enterprise and industrial policy (Chapter 20 $)^{25}$, education and culture (Chapter 26$)^{26}$, intellectual property law (Chapter 7$)^{27}$, customs union (Chapter 29) ${ }^{28}$, company law (Chapter 6) ${ }^{29}$, and external relations (Chapter 30 ${ }^{30}$. In 2018, four more followed: fisheries (Chapter 13$)^{31}$, financial and budgetary

25 Vlada Republike Srbije, Преговарачка позиција Републике СрбијезаМеђувладину конференцију о приступаюу Републике Србије Европској унији за Поглавље 20 "Предузетништво и индустријска политика" [Pregovaračka pozicija Republike Srbije za Međuvladinu konferenciju o pristupanju Republike Srbije Evropskoj unijiza Poglavlje 20 „Preduzetništvo i industrijska politika"], Beograd 2017, http://www.mei.gov.rs/upload/documents/pristupni_pregovori/pregovaracke _ pozicije/pregovaracka_pozicija_srbije_poglavlje_20.pdf [13.10.2019].

26 Vlada Republike Srbije, Преговарачка позиција Републике СрбијезаМеђувладину конференцију о приступаюу Републике Србије Европској унији за Поглавље 26 "Образовање и култура" [Pregovaračka pozicija Republike Srbije za Međuvladinu konferenciju o pristupanju Republike Srbije Evropskoj uniji za Poglavlje 26 „Obrazovanje i kultura”], Beograd 2016, http://www.mei.gov. rs/upload/documents/pristupni_pregovori/pregovaracke_pozicije/pregovaracka_pozicija_srbije_pg_26.pdf [13.10.2019].

27 Vlada Republike Srbije, Преговарачка позиција Републике Србијеза Међувладину конферениију оприступаюу Републике СрбијеЕвропскојунијиза поглавље [Pregovaračka pozicija Republike Srbije za Međuvladinu konferenciju o pristupanju Republike Srbije Evropskojunijiza poglavlje 7 Pravo intelektualne svojine], Beograd 2017, http://www.mei.gov.rs/upload/documents/pristupni_pregovori/pregovaracke_pozicije/Republika_Srbija_Pregovaracko_ poglavlje_7_srpska_verzija.pdf [13.10.2019].

28 Vlada Republike Srbije, Преговарачка позиција Републике Србијеза Међувладинуконференцију

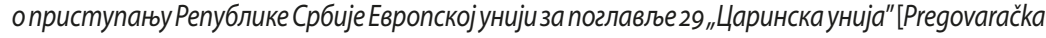
pozicija Republike Srbijeza Međuvladinu konferenciju o pristupanju RepublikeSrbije Evropskoj unijiza poglavlje 29 "Carinska unija"], Beograd 2017, http://www.mei.gov.rs/upload/documents/pristupni_pregovori/pregovaracke_pozicije/Pregovaracka_pozicija_29_srpski_tekst_19062017_locked. pdf [13.10.2019].

29 Vlada Republike Srbije, Преговарачка позичија Републике Србијеза Међувладинуконференцију о приступању Републике Србије Европској унији за Преговарачко поглавље 6 - "Право привредних друштава" [Pregovaračka pozicija Republike Srbije za Međuvladinu konferenciju o pristupanju Republike Srbije Evropskoj uniji za Pregovaračko poglavlje 6 - „Pravo privrednih društava"], Beograd 2017, http://www.mei.gov.rs/upload/documents/pristupni_pregovori/pregovaracke_pozicije/pregovaracka_pozicija_rs_pg_6.pdf [13.10.2019].

30 Vlada Republike Srbije, Преговарачка позиција Републике Србијеза Међувладинуконференцију о приступању Републике Србије Европској унији за Преговарачко поглавље зо - Економски односи са иностранством [Pregovaračka pozicija Republike Srbije za Međuvladinu konferenciju o pristupanju Republike Srbije Evropskoj uniji za Pregovaračko poglavlje 30 - Ekonomski odnosi sa inostranstvom], Beograd 2017, http://www.mei.gov.rs/upload/documents/pristupni_pregovori/pregovaracke_pozicije/pregovaracka_pozicija_rs_pg_30.pdf [14.10.2019].

31 Vlada Republike Srbije, Преговарачка позиција Републике Србијеза Међувладинуконференцију о приступању Републике Србије Европској унији за Преговарачко поглавље 13 - Рибарство [Pregovaračka pozicija Republike Srbije za Međuvladinu konferenciju o pristupanju Republike Srbije Evropskoj uniji za Pregovaračko poglavlje 13 - Ribarstvo], Beograd 2017, http://www.mei.gov.rs/ upload/documents/pristupni_pregovori/pregovaracke_pozicije/pg_pozicija_13.pdf [14.10.2019]. 
provisions (Chapter 33$)^{32}$, economic and monetary policy (Chapter 17$)^{33}$, and statistics (Chapter 18$)^{34}$. The following year, marked by widespread social criticism of the Serbian government, as expressed in mass civil protests, only one chapter, concerning financial services $\left(\right.$ Chapter 9) ${ }^{35}$, was opened.

The Republic of Serbia embarked on accession talks in January 2014 during the first intergovernmental conference, opening 17 out of 35 negotiation chapters in the next five years, two of which have since been temporarily shelved. Despite the internal situation in the country, Serbia has been applauded for its efforts and the pace of the accession process. In 2017, the $4^{\text {th }}$ Meeting of the Council for Stabilisation and Association expressed its approval of Serbia's involvement in fostering regional cooperation, the rule of law, as well as its progress in talks with Priština, which allowed it to open new negotiation chapters. At the same time, however, it called on the Serbian government to intensify reforms to promote the rule of law and fundamental rights, ensure the autonomy of democratic institutions and public administration, strengthen the market economy, and improve the business environment. Regional cooperation, but above all dialogue

32 Vlada Republike Srbije, Преговарачка позиција Републике Србијеза Међувладину конференцију о приступању Републике Србије Европској унији за Преговарачко поглавље з3-Финансијска и буиетска п итань [ [Pregovaračka pozicija Republike Srbije za Međuvladinu konferenciju o pristupanju Republike Srbije Evropskoj unijiza Pregovaračko poglavlje 33-Finansijska ibudžetska pitanja], Beograd 2017, http://www.mei.gov.rs/upload/documents/pristupni_pregovori/pregovaracke_ pozicije/pg_pozicija_33.pdf [14.10.2019].

33 Vlada Republike Srbije, Преговарачка позиција Републике Србијеза Међувладину конференцију о приступану Републике Србије Европској унији за Поглавље 17 „Економска и монетарна политика" [Pregovaračka pozicija Republike Srbije za Međuvladinu konferenciju o pristupanju Republike Srbije Evropskoj uniji za Poglavlje 17 „Ekonomska i monetarna politika"], Beograd 2018, http://www.mei.gov.rs/upload/documents/pristupni_pregovori/pregovaracke_pozicije/pozicija_pg_17.pdf [14.10.2019].

34 Vlada Republike Srbije,Преговарачка позиција Републике Србијеза Међувладину конференцију о приступаюу Републике СрбијеЕвропскојунији за Поглавље 18 "Cтатистика" [Pregovaračka pozicija Republike Srbije za Međuvladinu konferenciju o pristupanju Republike Srbije Evropskoj uniji za Poglavlje 18 „Statistika"], Beograd 2018, http://www.mei.gov.rs/upload/documents/pristupni_ pregovori/pregovaracke_pozicije/pozicija_pg_18.pdf [14.10.2019].

35 Vlada Republike Srbije, Преговарачка позичија Републике Србијеза Међувладинуконференцију o приступаюу Републике Србије Европској унији за Поглавље 9 "Финансијске услуге" [Pregovaračka pozicija Republike Srbije za Međuvladinu konferenciju o pristupanju Republike Srbije Evropskoj uniji za Poglavlje 9 „Finansijske us/uge"], Beograd 2018, http://www.mei.gov.rs/upload/documents/pristupni_pregovori/pregovaracke_pozicije/pregovaracka_pozicija_PG_9.pdf [14.10.2019]. 
with Priština, aimed at the 'normalisation of relations with Kosovo' was a formula that often cropped up in reports and summaries. The enigmatic phrase about the normalisation of relations is important to consider; defined as 'of key importance to the overall rate of progress' in the negotiations, it might go to confirm the tacit expectation that Serbia should recognise the independence of Kosovo, as already mentioned above ${ }^{36}$.

The assessment of the Serbian transformation progress in 2018 was no longer as favourable. This had to do with the deteriorating internal situation and the gradual shift from democracy toward the Hungarian political model (more below), accompanied by increasing social unrest. Reforms in the most important areas (chapters 23 and 24: the judicial system, fundamental rights and security, but above all, important legal provisions concerning the funding of political activities, public procurement, the fight against corruption and free access to information ${ }^{37}$ ), were judged as not sufficiently effective. The overall assessment, issued by the European Policy Centre, was a 'solid C' and the progress of reforms was described as noticeable. In view of the Freedom House ranking, published just four months later, also discussed below, this 'solid C' was still too high, considering that the measures of the Serbian government were described by the European Policy Centre as 'one of the least transparent... in the region' ${ }^{38}$.

The $10^{\text {th }}$ ministerial conference, which opened a new negotiation chapter (Chapter 9, devoted to financial services ${ }^{39}$ ), took place in June 2019. Subsequent conferences were planned for the second half of the year but have not yet been held. Compared to previous years, the pace of the accession process in Serbia has clearly slowed, hampered by the rising criticism of the current government, more vocal (and more per-

36 Council of the European Union, Fourth meeting of the Stabilisation and Association Council between the European Union and Serbia, 16.11.2017, https://www.consilium.europa.eu/pl/press/ press-releases/2017/11/16/fourth-meeting-of-the-stabilisation-and-association-council-betweenthe-european-union-and-serbia/ [13.10.2019].

37 Part 24 also includes the intimidation of and physical violence against journalists.

38 V. Popović, Srbiji solidna trojka za ostvarivanje poglavlja 23 i 24, VOA, 20.12.2018, https://www.glasamerike.net/a/srbiji-solidna-trojka-za-ostvarivanje-poglavlja-23-i-24/4709631.html [14.10.2019].

39 European Council, Council of the European Union, Tenth meeting of the Accession Conference with Serbia at Ministerial level, Brussels, 27 June 2019, https://www.consilium.europa.eu/pl/press/ press-releases/2019/06/27/tenth-meeting-of-the-accession-conference-with-serbia-at-ministerial-level-brussels-27-june-2019/ [13.10.2019]. 
sistent) on the part of Serbian society than the EU. Important charges levelled by Serbian social activists were to a certain extent reflected in a report on the accession progress, focused on specific areas, which was published at the end of May 2019. With respect to politics, the report emphasizes the need to create more space for genuine crossparty debate in order to forge a broad pro-European consensus and mentions the parliamentary boycott introduced by some parties at the beginning of 2019, which has significantly limited the dialogue in question. The ruling coalition's parliamentary practices, the report claims, have undermined parliament's oversight of the executive. Its tendency to take anti-democratic measures, in turn, has led to weekly civil protests against infringements of media freedom, manipulation and attempts to influence free and transparent elections, as reported by international observers ${ }^{40}$.

Another issue concerns the area of public administration, which, according to the report, has not been adequately reformed. Especially alarming is the political pressure on high-ranking executive staff. The report also indicated the need to recruit and retain qualified personnel to deal with matters related to the accession process and a coordinated monitoring and reporting system for public administration reform, as well as public finance reform and its management $t^{41}$.

The report favourably assessed reforms undertaken in the judicial system, pointing out that Serbia has made 'limited' progress and achieved 'some' level of preparation, following the guidelines only in part. However, it also mentioned that the process of constitutional reform intended to align the constitution with European judiciary standards is still ongoing. The areas in need of reform, according to the report, include the system of appointing and evaluating judges and prosecutors, which should rely on merit-based criteria. A special point of interest is the degree of political influence on the courts ${ }^{42}$.

40 Delegation of the European Union to the Republic of Serbia, Ključni zaključci izveštaja o Srbiji za 2019. godinu, 29.05.2019, http://europa.rs/kljucni-zakljucci-izvestaja-o-srbiji-za-2019-godinu/ [15.10.2019]; European Commission, Serbia 2019 Report, Brussels, 29.05.2019, https://ec.europa. eu/neighbourhood-enlargement/sites/near/files/20190529-serbia-report.pdf [15.10.2019]. 
Another issue discussed in the report was the fight against corruption, which the Serbian government has waged only 'to a limited extent'. The report mentioned the laws introduced in this respect in 2018 and 2019, but pointed to the lack of their measurable impact, due to the short time that has elapsed since their introduction. The area was judged as particularly sensitive and in need of scrupulous review on account of the widespread corruption at the top state level, which may make it more difficult to prosecute crimes and issue impartial verdicts in such cases. The same holds for organised crime, as Serbia only shows 'some level of preparation' to combat the problem. A new chapter of the criminal code dealing with economic crime was only being implemented when the report was published, as was a new strategy for fighting organised crime (2019-2023), based on advanced technologies; at the same time, no progress had been made to meet the recommendations of the previous report ${ }^{43}$.

Another area that has received a broad legal framework but failed to be enforced, altogether or in part, included the issue of fundamental rights, including minority rights. The report applauded the new media strategy blueprint but expressed concern over its exclusively literal and declarative character. No real progress has been made, the report claims, to guarantee the freedom of speech and the rights of discriminated persons (the LGBT community, people with disabilities, HIV/AIDS patients, etc. $)^{44}$.

On a political level, however, the report praised the Serbian government for its involvement in regional cooperation and progress in the ongoing dialogue with Priština. It also applauded Serbian efforts to stabilise migration flows to the EU. The country has made significant advances in the implementation of an integrated border management strategy and adopted a plan to prevent illegal migration ${ }^{45}$.

In economic terms, Serbia merited a fair assessment. The positive phenomena included some degree of preparation to develop an

43 According to the report, there were no registers of effective investigations, indictments or final convictions (their number was defined as small in the document) in cases concerning organised crime, including financial investigations, which could lead to recording confiscation of proceeds from crime. See Delegation of the European Union to the Republic of Serbia, Ključni zaključci... Ibidem.

Ibidem. 
efficient market economy, improvements in debt sustainability and the financial sector. Positive advancements were also observed in the labour market (except with regard to the young). The negatives included external imbalances and their financing, the persistent, high inflation, the slow pace of structural reform in public administration, fiscal administration and public enterprise, which continue to slow down the progress of reforms, as well as the lack of sufficient investment. Excessive state intervention also was deemed a problem, accompanied by an underdeveloped private sector, insufficient efforts to ensure fair competition and a weak rule of law that serves to reinforce these trends. On the other hand, legislative reforms aimed at ensuring compliance with EU standards were assessed positively, even though further progress is still required, especially in areas such as public procurement, statistics, foreign relations, social and employment policy, monetary policy, financial services and environmental protection. Priority areas in urgent need of speedy reform included state control, fiscal discrimination on alcohol, and the limited competition in card payment systems ${ }^{46}$.

\section{Challenges to Serbian democracy 2 oin an era of populism}

Serbia falls in with the pan-European trend of the renascent popularity of the right-wing, tinged with the specific flavour of Central Europe, and the rise of right-wing populists promising real change, which, as shown by the election results, seems more important to voters than the ruling party's attempts to limit democracy. Political parties have now changed into organisations that mine public resources through corruptible officials, often mere dilettantes with no qualifications to hold a post in public administration, state institutions or enterprises (a similar phenomenon is also underway in Poland, where critics interpret the exorbitant salaries claimed by such individuals, on top of their self-awarded bonuses and tax breaks, as a form of compensation for their long wait to get into power). Favouritism is widespread; lucrative jobs are handed out to the followers of the ruling party or 
the president. The same trend plagues not only Serbia but also other Central European countries (Hungary being an excellent case in point), and while in the first two decades after the fall of communism this did not seem so glaring, in the 2010s, the practice is no longer as discreet. It fits in, however, with the widescale acceptance of commercial populism; society openly condones such conduct because of the accompanying changes in the distribution of various subsidies, e.g., in the form of welfare. The government boosts the living conditions and the citizens, who appreciate the improvement, turn a blind eye to its deviation from democratic principles and the rule of law. In Serbia, however, the high level of support enjoyed by the ruling party may have to do not so much with the improvements in the quality of life as with the actual reforms that the SNS implemented after 2012, and for which the Serbs had waited for more than a decade. Add to that the political course for the West (including the acceptance of EU values) and it is plain to see why Vučić and his party, with such longstanding nationalist and right-wing traditions, should continue to enjoy a broad capital of social trust; its supporters believe that despite the new political and economic policy, Vučić will still stand guard over Serbian national interests (while the predecessors of the president and his party in the first decade of the $21^{\text {st }}$ century also spoke in defence of the national interest, their declarations again never went beyond lip-service).

Vučićs political opponents argue that for the West, which has placed more trust in the president than in any other Serbian politician, free media, fair elections, human rights and democratic liberties are essentially far less important than an agreement between Belgrade and Priština; this is backed by Western diplomats themselves, who point out that as long as Vučić and his team are in power, talks between Belgrade and Priština are guaranteed to continue ${ }^{47}$. This situation mirrors the events of 1996/1997 when the opponents of Milošević took to the streets to protest against rigged local elections. Not unlike now, the opposition, which closed ranks to stage the protests, failed to attract Western support (despite the efforts of the Serbian Prime 
Minister-to-be and Democratic Party leader, Zoran Đinđić). The reason was that the West did not quite know what policies to expect of the opposition, unlike the already well-known Milošević and his party ${ }^{48}$. The same holds true today: the team of Vučić, who have waged an effective political offensive since 2015 on a scale unprecedented in the history of Serbia, have managed to build up a favourable PR image both in Eastern and Western Europe. For this reason, not unlike 22 years ago, when the West argued that the Serbian opposition was more nationalist in attitude than the then-steward of Serbia, today, the image of the Serbian president and his government is also more moderate than that of some parties in the Alliance for Serbia (which includes the likes of the right-wing, Eurosceptic, conservative and nationalist Dveri, Fatherland, or Healthy Serbia, the last of which is not represented in parliament at the moment) ${ }^{49}$.

This phenomenon has been addressed and publicly lambasted by the opponents of the ruling party, but the problem in Serbia, not unlike in Poland, is that there is no real political alternative to the status quo. The weakness of the Serbian opposition lies in the fact that some of its parties were already in power before 2012, demonstrating a complete lack of transformative ability and failing to introduce any real reforms for a decade. The pro-European parties of the opposition base their programme on neoliberal dogma and have no real grounds to question the policies enforced by Vučić, such as the market economy or integration with the EU. This allows the government to claim that the opposition has no independent political programme and that its attacks on the president are motivated by mere personal aversion. The anti-European and nationalist wing of the opposition, on the other hand, is 'trapped in the national problem, with eyes set on the kingdom of heaven and can see nothing else beyond ${ }^{50}$.

48 For more, see M. Korzeniewska-Wiszniewska, Serbia pod rządami Slobodana Miloševicia. Serbska polityka wobec rozpadu Jugosławii w latach dziewięćdziesiątych XX W., Kraków 2008, p. 195 and next.

49 Данас Запад подржава Вучића ьбог Косова, у Савез за Србију немају поверења [Danas Zapad podržava Vučića zbog Kosova, u Savez za Srbiju nemaju poverenja], Nova srpska politička misao, 05.03.2019, http://www.nspm.rs/hronika/danas-zapad-podrzava-vucica-zbog-kosova-u-savezza-srbiju-nemaju-povorenja.html [14.10.2019].

50 M. Samardžić, Šetnje nisu dovoljne - organizacija i program kao Arhimedova tačka i/ili Ahilova peta, Nova srpska politička misao, 14.01.2019, http://www.nspm.rs/kuda-ide-srbija/ 
Importantly, the opposition in Serbia is too diverse to come up with a programme that would be competitive and attractive enough to rival that of the SNS and guarantee electoral victory. Another thing is the issue of actually delivering on electoral promises, where we see another analogy with the social and political context in Poland. As long as they do not affect everyday life directly, legal violations and the breach of democratic principles of law are not perceived as a problem by the average citizen; they pale in contrast with the dynamism of change that, together with the implementation of the party's programme, shows the government as one that reckons with its citizens and delivers on their expectations. The opposition faces the political challenge of building a coherent and credible image of a coalition that brings together Eurosceptic, nationalist conservatives on the one hand, and pro-European, left-wing social democrats on the other. The example of Serbia, not unlike that of Poland or Hungary, demonstrates the failure of an opposition alliance whose only shared postulate is to abolish the incumbent government by exposing its flaws (corruption, favouritism, connections to the previous regime, shady business deals or embarrassing verbal blunders that lay bare their dilettantism and low qualifications) is not effective.

The lack of an effective political opposition in Serbia has mobilised citizens to take to the streets to demonstrate against the government. Protest leaders accuse the president of failing to engage in dialogue with the citizens. However, analysts view these spontaneous protests as a civic movement, likely to soon lose momentum and fizzle out without achieving any tangible change, which could come through a more effective, structured political movement, running on an antisystem ticket ${ }^{51}$. In recent months, associations have mushroomed to unite individuals dissatisfied with the rule of Vučić and his team. The most popular among these, One in Five Million, established at the end of January $2019^{52}$, aims to give systematic form to the postulates

setnje-nisu-dovoljne-organizacija-i-program-kao-arhimedova-tacka-i/ili-ahilova-peta. html?alphabet=I\#yvComment209241 [10.06.2019].

51 The problem, however, is that any activity that takes the form of a party and activists' contact with politics is perceived automatically as entering the world of clientelism and corruption and thereby losing credibility. See M. Samardžić, Šetnje nisu dovoljne...

52 U Beogradu osnovano Udruženje "1 od 5 miliona", Danas, 27.02.2019, https://www.danas.rs/politika/osnovano-udruzenje-1-od-5-miliona/ [10.06.2019]. 
made by the protesters and engage in dialogue with the authorities, who have thus far completely ignored and played down their activities since December 2018.

Methods employed by the authorities against the demonstrators, but also the opposition at large, are designed to denigrate them in the eyes of the public (or potential voters); similar strategies can be observed in Poland and Hungary. The most basic of these is the attempt to revile an opponent: in Serbia, protesters are labelled as Albanian lobbyists, in Poland as the 'worse sort', and in both countries, condemned as 'traitors to the fatherland. The scale and importance of the protests are also routinely played down, or protesters are cast as the supporters of or even direct agents of external powers, in Serbia, described as foreign-sponsored, and in Poland, on the payroll of the former communist regime (the so-called 'red rabble'). In contrast to Serbia, however, in Poland most of the struggle is verbal: violence only occasionally erupts between different groups of protesters; sometimes effigies are publicly burned. The only exception was the assassination of the mayor of Gdańsk, Paweł Adamowicz, known for his liberal ideas, which the authorities still refuse to treat as politically motivated, even though the killer himself admitted he was driven by his hatred of the opposition, as represented by the mayor. In Serbia, there has been an ongoing campaign of intimidation and acts of violence against protesters and opposition politicians are the order of the day (e.g., spraying water, throwing petards into the crowd). The opposition's calls for dialogue are persistently ignored by the authorities (in Poland and Serbia alike), set on promoting the propaganda of success, which cannot be hindered by a mere 'handful' of dissatisfied protesters ${ }^{53}$.

The establishment casts civil protests as a token of democracy (after all, people are allowed to air their grievances), but definitely not as a revolution or a broader 'Balkan Spring' (including not only protests in Serbia but also in Albania and Montenegro $)^{54}$, which could have a real impact on reforms, because in its eyes, as mentioned before, it does not

53 S. Čongradin, Anasonović: Pauza za Uskrs nije opcija, Danas, 26.04.2019, https://www.danas.rs/ politika/anasonovic-pauza-za-uskrs-nije-opcija/ [10.06.2019].

54 SeeV. Pešić, Slobodna volja za miting, moćza kontramiting, Peščanik, 23.04.2019, https://pescanik. net/slobodna-volja-za-miting-moc-za-kontramiting/ [14.10.2019]; V. Gligorov, Brojevi, Peščanik, 01.05.2019, https://pescanik.net/brojevi/ [14.10.2019]. 
represent the majority view. The establishment relativizes the causes of protest and plays down the numbers of protesters to show that neither the demonstrators nor their postulates enjoy broader social support. Extended over a period of time, protests in Serbia, such as those of 1996/1997, have always shown a variable dynamic and a tendency for social involvement to wane over time; the government probably hopes that the current demonstrations will likewise finally fizzle out.

\section{Conclusion}

- Thirty years after the fall of communism, Serbs, not unlike other Eastern European nations, especially Poland and Hungary, two theoretical examples of successful transformation in previous decades, are still waiting for effective reforms to patch up the national economy, improve living conditions and put Serbia on an equal footing with, if not the strongest EU member states, then at least the countries of the region, some of which already enjoy EU membership. In their eyes, this objective can be achieved even at the expense of abandoning the principles of democracy, which seem to have recently lost currency, as evidenced by the case of Poland, Hungary, and now Serbia, with parliamentary elections after 2012 (in Poland and Hungary, also the European Parliament elections in 2019). Even though there has long been talk of a resurgent wave of right-wing movements and their popularity throughout Europe, in the West, the phenomenon underway occurs under the conditions of stable democracy; in Central Europe and the Balkans, however, it simply undermines the relatively recent democratic gains, often not very well established, for the sake of improving the financial situation of the state and its citizens. Protesters in Serbia, both opposition politicians and social activists, should focus on deeper social grievances, rather than democracy and free media alone, as these arguments have been shown to fail in the struggle against the ruling power. To convince the unconvinced, the weakness of the state should be exposed in areas that more closely affect the people, such as workers' rights or the disastrous state of public healthcare. This is where analysts see good potential for effective opposition.

Vučić seems to be the first Serbian politician after 2000 (apart from Đinđic), who truly wants to talk to and cooperate with Western Europe effectively, who started the process of real and dynamic change 
in Serbia, which is also perceived by society; who started an effective dialogue with Priština, and who clearly declares a pro-EU direction of the Serbian state, even at the expense of Moscow's loss of confidence ${ }^{55}$. The EU trusts him as an effective politician with whom common goals can be achieved. Another issue that seems not to interest EU politicians is Serbia's internal situation ${ }^{56}$, ruled by a narrow party elite in a way now defined as 'stabilocracy' (an amalgam of 'stabilisation' and 'autocracy'). The fact is that the paths leading to integration and the authoritarian turn of the state will have to cross at some point. The question is whether there will be a moment at which this authoritarianism has gone so far that it will close Serbia's door to the EU at last, or will it come after accession when EU standards will require Vučić to democratise the state?

\section{References}

Council of the European Union, Fourth meeting of the Stabilisation and Association Council between the European Union and Serbia, 16.11.2017, https://www.consilium.europa.eu/pl/press/ press-releases/2017/11/16/ fourth-meeting-of-the-stabilisation-and-association-council-betweenthe-european-union-and-serbia/ [13.10.2019].

Čongradin S., Anasonović: Pauza za Uskrs nije opcija, Danas, 26.04.2019, https://www.danas.rs/politika/anasonovic-pauza-za-uskrs-nije-opcija/ [10.06.2019].

Аанас Запад подржава Вучића кбог Косова, у Савез за Србију немају поверења [Danas Zapad podržava Vučića zbog Kosova, u Savez za Srbiju nemaju poverenja], Nova srpska politička misao, 05.03.2019, http:// www.nspm.rs/hronika/danas-zapad-podrzava-vucica-zbog-kosova-usavez-za-srbiju-nemaju-povorenja.html [14.10.2019].

Delegation of the European Union to the Republic of Serbia, Ključni zaključci izveštaja o Srbijiza 2019. godinu, 29.05.2019, http://europa.rs/kljucni-zakljucci-izvestaja-o-srbiji-za-2019-godinu/ [15.10.2019].

55 ЛеонидСавин:Путин немавелико поверењеуВучића, усрпским медијимасествара погрешна слика о њиховом односу [Leonid Savin: Putin nema veliko poverenje u Vučića, u srpskim medijima se stvara pogrešna slika o njihovom odnosu], Nova srpska politička misao, 29.08.2018, http://www. nspm.rs/hronika/leonid-savin-putin-nema-veliko-poverenje-u-vucica-u-srpskim-medijima-sestvara-pogresna-slika-o-njihovom-odnosu.html?alphabet=c\#yvComment202264 [13.11.2019]. Also of Albania and Montenegro. 
European Commission, Serbia 2019 Report, Brussels, 29.05.2019, https:// ec.europa.eu/neighbourhood-enlargement/sites/near/files/20190529-serbia-report.pdf [15.10.2019].

European Council, Council of the European Union, Tenth meeting of the Accession Conference with Serbia at Ministerial level, Brussels, 27 June 2019, https://www.consilium.europa.eu/pl/press/press-releases/2019/o6/27/ tenth-meeting-of-the-accession-conference-with-serbia-at-ministeriallevel-brussels-27-june-2019/ [13.10.2019].

Freedom House, Freedom in the World 2018, https://freedomhouse.org/report/freedom-world/freedom-world-2018 [13.10.2019].

Freedom House, Freedom in the World 2019, https://freedomhouse.org/report/freedom-world/2019/serbia [13.10.2019].

Fule: Ne tražimo od Srbije da prizna Kosovo, Klix, 23.10.2014, https:// www.klix.ba/vijesti/regija/fule-ne-trazimo-od-srbije-da-prizna-kosovo/141023173 [07.10.2019].

Gashi S., Novaković I., Od tehničkih sporazuma do sveobuhvatne normalizacije. Odnosi između Beograda i Prištine, Beograd 2017, http://library. fes.de/pdf-files/bueros/belgrad/13821.pdf [08.10.2019].

Gligorov V., Brojevi, Peščanik, 01.05.2019, https://pescanik.net/brojevi/ [14.10.2019].

Karabeg O., Da li će Vučić vladati Srbojom dokle bude hteo, Radio Slobodna Evropa, 06.08.2017, https://www.slobodnaevropa.org/a/da-li-ce-vudicvladati-srbijom-dokle-bude-hteo/2866o615.html [13.10.2019].

Konferencija o pristupanju Evropsku Uniju, Приступни документ. Заједничка позиција Европске Уније. Поглавље 35 остала питања [Pristupni dokument. Zajednička pozicija Evropske Unije. Poglavlje 35 ostala pitanja], Brisel 2015, http://www.mei.gov.rs/upload/documents/ pristupni_pregovori/pregovaracke_pozicije/pg35_zajednicka_pozicija_ eu.pdf [13.10.2019].

Korzeniewska-Wiszniewska M., Charakter współczesnych relacji serbsko-rosyjskich, [w:] I. Stawowy-Kawka (ed.), Międzycywilizacyjny dialog w świecie stowiańskim w XX i XXI wieku. Historia - religia - kultura polityka, Kraków 2012.

Korzeniewska-Wiszniewska M., Serbia pod rządami Slobodana Miloševicia. Serbska polityka wobec rozpadu Jugostawii w latach dziewięćdziesiątych $X X$ w., Kraków 2008.

Kosovo Progress Essential, Fule Tells Serbia, Balkan Insight, 16.02.2012, https://balkaninsight.com/2012/o2/16/progress-in-kosovo-dispute-remains-condition/ [07.10.2019].

Kosovski Demokratski Institut, Dijalog Kosovo-Srbija: izazovi i dalji koraci, March 2018, http://kdi-kosova.org/wp-content/uploads/2018/o4/18-Sfidat-SRB-04.pdf [08.10.2019].

Иеонид Савин: Путин нема велико поверене у Вучића, у сриским медијима се ствара погрешна слика о ғиховом односу [Leonid Savin: Putin nета veliko poverenje u Vučića, u srpskim medijima se stvara pogrešna slika 
o njihovom odnosu], Nova srpska politička misao, 29.08.2018, http://www. nspm.rs/hronika/leonid-savin-putin-nema-veliko-poverenje-u-vucica-u-srpskim-medijima-se-stvara-pogresna-slika-o-njihovom-odnosu. html?alphabet=c\#yvComment202264 [13.11.2019].

Ministarstvo spoljnih poslova Republike Srbije, Regionalne inicijative, http://www.mfa.gov.rs/sr/index.php/spoljna-politika/eu/regionalnasaradnja?lang=lat [20.09.2019].

Ministarstvo za evropske integracije Republike Srbije, Хронолошки преглед односа Републике Србије и Европске Уније од 20о5. године до отваранја приступних преговора [Hronološki pregled odnosa Republike Srbije i Evropske Unije od 2005. godine do otvaranja pristupnih pregovora], http:// kurs-pregovori.mei.gov.rs/?page=uvod [14.10.2019].

Ministarstvo za evropske integracije Repulike Srbije, Istorijat odnosa Srbije i EU, http://www.mei.gov.rs/srl/srbija-i-eu/istorijat-odnosa-srbije-i-eu/ [09.10.2019].

Ministarstvo za evropske integracije Republike Srbije, Споразум о стабилизачији и придруживању између Европских заједнича и юихових држава чланииа, са једне стране, и Републике Србије, са друге стране [Sporazum o stabilizaciji i pridruživanju između Evropskih zajednica $i$ njihovih država članica, sa jedne strane, i Republike Srbije, sa druge strane], http://www.mei.gov.rs/upload/documents/sporazumi_sa_eu/ssp_ prevod_sa_anexima.pdf [09.10.2019].

Pešić V., Slobodna volja za miting, moć za kontramiting, Peščanik, 23.04.2019, https://pescanik.net/slobodna-volja-za-miting-moc-za-kontramiting/ [14.10.2019].

Popović V., Srbiji solidna trojka za ostvarivanje poglavlja 23 i 24, VOA, 20.12.2018, https://www.glasamerike.net/a/srbiji-solidna-trojka-za-ostvarivanje-poglavlja-23-i-24/4709631.html [14.10.2019].

Samardžić M., Šetnje nisu dovoljne - organizacija i program kao Arhimedova tačka i/ili Ahilova peta, Nova srpska politička misao, 14.01.2019, http://www.nspm.rs/kuda-ide-srbija/setnje-nisu-dovoljne-organizacijai-program-kao-arhimedova-tacka-i/ili-ahilova-peta.html?alphabet= l\#yvComment209241 [10.06.2019].

Srpska napredna stranka, I'm obsessed with Kosovo, 15.05.2018, https://www. sns.org.rs/en/novosti/vesti/vucic-im-obsessed-kosovo [11.10.2019].

Stojanović M., Zapad podržava Vučicia zbog kosovskog pitanja, Danas, 05.03.2019, https://www.danas.rs/politika/zapad-podrzava-vucica-zbogkosovskog-pitanja/ [09.06.2019].

U Beogradu osnovano Udruženje "1 od 5 miliona”, Danas, 27.02.2019, https:// www.danas.rs/politika/osnovano-udruzenje-1-od-5-miliona/ [10.06.2019].

Vlada Republike Srbije, Преговарачка позиција Републике Србије sа међународну конберенцију о пиступању Републике Србије Европској Унији за проговорачко поглавље 5 - јавне набавке [Pregovaračka pоzicija Republike Srbije za medunarodnu konferenciju o pristupanju Republike Srbije Evropskoj Uniji za progovoračko poglavlje 5 - javne nabavke], 
Beograd 2016, http://www.mei.gov.rs/upload/documents/pristupni_pregovori/pregovaracke_pozicije/pg_pozicija_pg_5.pdf [13.10.2019].

Vlada Republike Srbije, Преговарачка позиција Републике Србије за Међувладину конберенцију о приступану Републике Србије Европској унији за Преговарачко поглавље 6 - „Право привредних друштава” [Pregovaračka pozicija Republike Srbije za Međuvladinu konferenciju o pristupanju Republike Srbije Evropskoj uniji za Pregovaračko poglavlje 6 - „Pravo privrednih društava”, Beograd 2017, http://www.mei.gov.rs/ upload/documents/pristupni_pregovori/pregovaracke_pozicije/pregovaracka_pozicija_rs_pg_6.pdf [13.10.2019].

Vlada Republike Srbije, Преговарачка позииија Републике Србије за Међувладину конберенцију ориступану Републике Србије Европској унији за поглавље 7 Право интелектуалне својине [Pregovaračka pozicija Republike Srbije za Međuvladinu konferenciju o pristupanju Republike Srbije Evropskoj uniji za poglavlje 7 Pravo intelektualne svojine], Beograd 2017, http://www.mei.gov.rs/upload/documents/pristupni_pregovori/pregovaracke_pozicije/Republika_Srbija_Pregovaracko_poglavlje_7_srpska_verzija.pdf [13.10.2019].

Vlada Republike Srbije, Преговарачка позиција Републике Србије за Међувладину конберенцију о приступању Републике Србије Европској унији за Поглавље 9 „Финансијске услуге” [Pregovaračka pozicija Republike Srbije za Međuvladinu konferenciju o pristupanju Republike Srbije Evropskoj uniji za Poglavlje 9 „Finansijske usluge”], Beograd 2018, http:// www.mei.gov.rs/upload/documents/pristupni_pregovori/pregovaracke_ pozicije/pregovaracka_pozicija_PG_9.pdf [14.10.2019].

Vlada Republike Srbije, Преговарачка позичија Републике Србије за Међувладину конберенцију о приступању Републике Србије Европској унији за Преговарачко поглавље 13 - Рибарство [Pregovaračka pozicija Republike Srbije za Međuvladinu konferenciju o pristupanju Republike Srbije Evropskoj uniji za Pregovaračko poglavlje 13 - Ribarstvo], Beograd 2017, http://www.mei.gov.rs/upload/documents/pristupni_pregovori/ pregovaracke_pozicije/pg_pozicija_13.pdf [14.10.2019].

Vlada Republike Srbije, Преговарачка позиција Републике Србије за Међувладину конберениију о приступању Републике Србије Европској унији за Поглавље 17 „Економска и монетарна политика" [Pregovaračka pozicija Republike Srbije za Meduvladinu konferenciju o pristupanju Republike Srbije Evropskoj uniji za Poglavlje 17 „Ekonomska i monetarna politika”], Beograd 2018, http://www.mei.gov.rs/upload/ documents/pristupni_pregovori/pregovaracke_pozicije/pozicija_pg_17. pdf [14.10.2019].

Vlada Republike Srbije, Преговарачка позиција Републике Србије за Међувладину конберенцију о пиступану Републике Србије Европској унији за Поглавље 18 „Статистика” [Pregovaračka pozicija Republike Srbije za Međuvladinu konferenciju o pristupanju Republike Srbije Evropskoj uniji za Poglavlje 18 „Statistika”, Beograd 2018, http://www.mei.gov. 
rs/upload/documents/pristupni_pregovori/pregovaracke_pozicije/pozicija_pg_17.pdf [14.10.2019].

Vlada Republike Srbije, Преговарачка позииија Републике Србије за Међувладину конферениију о приступању Републике Србије Европској унији за Поглавље 20 „Предузетништво и индустријска политика" [Pregovaračka pozicija Republike Srbije za Međuvladinu konferenciju o pristupanju Republike Srbije Evropskoj uniji za Poglavlje 20 „Preduzetništvo i industrijska politika”, Beograd 2017, http://www.mei. gov.rs/upload/documents/pristupni_pregovori/pregovaracke_pozicije/ pregovaracka_pozicija_srbije_poglavlje_2o.pdf [13.10.2019].

Vlada Republike Srbije, Преговарачка позиција Републике Србије у оквиру Међувладине конференције о приступању Републике Србије Европској унији за Поглавље 23. „Правосуђе и основна права” [Pregovaračka pozicija Republike Srbije u okviru Meduvladine konferencije o pristupanju Republike Srbije Evropskoj uniji za Poglavlje 23. „Pravosude i osnovna pra$v a$ "], Beograd 2016, http://www.mei.gov.rs/upload/documents/pristupni_ pregovori/pregovaracke_pozicije/pg_23_pregovaracka_pozicija_srbije. pdf [13.10.2019].

Vlada Republike Srbije, Преговарачка позиције Републике Србије за Међувладину конференцију о пиступану Републике Србије Европској унији за Поглавље 25 „Наука и истраживање” [Pregovaračka pozicije Republike Srbije za Međuvladinu konferenciju o pristupanju Republike Srbije Evropskoj uniji za Poglavlje 25 „Nauka i istraživanje”, Beograd 2016, http://www.mei.gov.rs/upload/documents/pristupni_pregovori/pregovaracke_pozicije/pg_poglavlje_pg_25.pdf [13.10.2019].

Vlada Republike Srbije, Преговарачка позичија Републике Србије за Међувладину конберенцију о приступану Републике Србије Европској унији за Поглавље 26 „Образовање и култура” [Pregovaračka pozicija Republike Srbije za Meduvladinu konferenciju o pristupanju Republike Srbije Evropskoj uniji za Poglavlje 26 „Obrazovanje i kultura”, Beograd 2016, http://www.mei.gov.rs/upload/documents/pristupni_pregovori/pregovaracke_pozicije/pregovaracka_pozicija_srbije_pg_26.pdf [13.10.2019]. Vlada Republike Srbije, Преговарачка позиција Републике Србије за Међувладину конференцију о пиступану Републике Србије Европској унији за поглавље 29 „Царинска унија” [Pregovaračka pozicija Republike Srbije za Međuvladinu konferenciju o pristupanju Republike Srbije Evropskoj uniji za poglavlje 29 „Carinska unija”, Beograd 2017, http://www.mei. gov.rs/upload/documents/pristupni_pregovori/pregovaracke_pozicije/ Pregovaracka_pozicija_29_srpski_tekst_19062017_locked.pdf [13.10.2019].

Vlada Republike Srbije, Преговарачка позиција Републике Србије за Међувладину конферениију о приступању Републике Србије Европској унији за Преговарачко поглавље зо - Економски односи са иностранством [Pregovaračka pozicija Republike Srbije za Međuvladinu konferenciju o pristupanju Republike Srbije Evropskoj uniji za Pregovaračko poglavlje 30 -Ekonomski odnosi sa inostranstvom], Beograd 2017, http:// 
www.mei.gov.rs/upload/documents/pristupni_pregovori/pregovaracke_ pozicije/pregovaracka_pozicija_rs_pg_3o.pdf [14.10.2019].

Vlada Republike Srbije, Преговарачка позиција Републике Србије за Међувладину конберенцију о приступану Републике Србије Европској унији за поглавље 32 Финансијски надзор [Pregovaračka pozicija Republike Srbije za Međuvladinu konferenciju o pristupanju Republike Srbije Evropskoj uniji za poglavlje 32 Finansijski nadzor], Beograd 2014, http:// www.mei.gov.rs/upload/documents/pristupni_pregovori/pregovaracke_ pozicije/pg32_pregovaracka_pozicija_srb.pdf [13.10.2019].

Vlada Republike Srbije, Преговарачка позииија Републике Србије за Међувладину конберенцију о пиступану Републике Србије Европској унији за Преговарачко поглавље 33 - Финансијска и буцетска питањь [Pregovaračka pozicija Republike Srbije za Međuvladinu konferenciju o pristupanju Republike Srbije Evropskoj uniji za Pregovaračko poglavlje 33 - Finansijska i budžetska pitanja], Beograd 2017, http://www.mei. gov.rs/upload/documents/pristupni_pregovori/pregovaracke_pozicije/ pg_pozicija_33.pdf [14.10.2019].

Vučković Z., Transformacje systemu społeczno-politycznego w Serbii po 2000 r., Kraków 2014 [Doctorate not published. Access courtesy of the author]. 